\title{
Systemic side effects of eye drops: a pharmacokinetic perspective
}

This article was published in the following Dove Press journal:

Clinical Ophthalmology

7 December 2016

Number of times this article has been viewed

\author{
Andre Farkouh' \\ Peter Frigo ${ }^{2}$ \\ Martin Czejka ${ }^{1,3}$ \\ 'Division of Clinical Pharmacy and \\ Diagnostics, Faculty of Life Sciences, \\ University of Vienna, ${ }^{2}$ Department \\ of Gynecologic Endocrinology and \\ Reproductive Medicine, Medical \\ University of Vienna, ${ }^{3}$ Austrian \\ Society of Applied Pharmacokinetics, \\ Vienna, Austria
}

\begin{abstract}
When administering eye drops, even when completely correctly applied, several routes of absorption are possible and excess amounts can sometimes cause an unwanted systemic bioavailability of the drops when not completely absorbed into the eye. Furthermore, the concentration of active ingredients in such medicinal preparations is usually very high, so that despite the correct application of the recommended dose, considerable amounts may be absorbed in an unwanted manner through various routes. Children are subject to a much higher risk of systemic side effects because ocular dosing is not weight adjusted and physiological development (eg, liver status) differs from that of adults. There is a lack of information about pediatric dosing in the current literature. This review summarizes the most important clinically relevant systemic side effects that may occur during ophthalmic eye treatments. In this review, we discuss general pharmacokinetic considerations as well as the advantages, disadvantages, and consequences of administering drugs from some important drug groups to the eye.
\end{abstract}

Keywords: pharmacodynamics, CYP, dosing, children

\section{Introduction}

\section{Pharmacokinetic considerations}

Pharmacokinetics plays an essential role in drug therapy in regard to dose individualization, pediatrics, geriatrics, gender therapy, multiple dosing, drug-drug interactions, and others. Pharmacokinetics usually describes the time-dependent movement of a drug from one compartment of the body to another until the drug, or its metabolite(s), is eliminated from the body. Some areas of the body are characterized by multiple compartments (eg, eye, brain, and placenta) that impede a safe and efficient drug therapy. ${ }^{1}$ Pharmacokinetics of drugs administered into the eye can best be described by looking at the different compartments that are protected by a bloodocular barrier similar to the blood-brain or blood-placental barrier. When applying eye drops, even when correctly administered, several routes of absorption are possible, as depicted in Figure 1. There are different methods of delivery of ocular medications to the eye, namely, topical, local ocular (intravitreal, subconjunctival, retrobulbar, and intracameral), and systemic.

The most suitable method of administration depends on which area of the eye is the target for the remedy. Figure 1 provides an overview of the ocular absorption pathways of ocular drugs.

The volume of commercial drop dispensers $(25-50 \mu \mathrm{L})$ generally exceeds the capacity of the conjunctival sac (only $10 \mu \mathrm{L}$ ), so that the major portion of the liquid drains out of the eye and onto the eyelids and cheeks, where further absorption may occur. ${ }^{2}$ Generally, the capacity of the conjunctival sac depends on several factors, such as
Correspondence: Andre Farkouh Division of Clinical Pharmacy and Diagnostics, Faculty of Life Sciences, University of Vienna, Althanstrasse 14, A- 1090 Vienna, Austria

Tel +43 | 427755579

Email andre.farkouh@univie.ac.at 


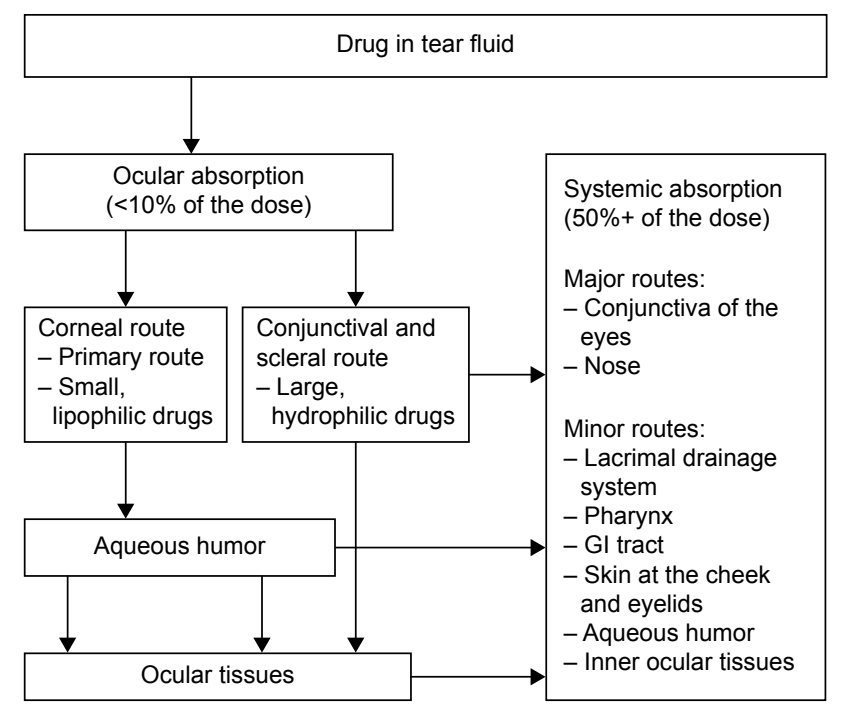

Figure I Possible absorption pathways of a drug administered into the eye. Abbreviation: Gl, gastrointestinal.

blink rate, position (applying when standing or lying down), and the means of application. Other factors are related to the physicochemical properties of the drugs in the eye drops, such as $\mathrm{pH}$ value, ionization or osmolarity (which can cause higher blink rates), and increased lacrimation. In addition, the amount of the drained drug and its extent of absorption depend on the volume of the eye drops. According to the literature, topical therapy has been reported as effective in treating the conjunctiva, cornea, anterior chamber, and iris. ${ }^{3}$ This means of administration implies that the eye drops are on the surface of the eye only for a short time. Therefore, bioavailability has to be classified as extremely low and is reported in the literature to be in the order of $5 \%-10 \% .{ }^{4,5}$ Even when trying to achieve a longer exposure time, by using gels or inserts for instance, the corneal epithelium and conjunctival epithelium act as natural barriers, which complicates and limits the absorption of the drug.

The eyes are usually treated by topical therapy, but sometimes systemic therapy is required (eg, posterior segment therapy). The blood-ocular barriers can restrain absorption of less lipophilic drugs; however, any inflammation caused will increase blood flow, which will initially allow greater drug concentrations to reach the site. ${ }^{6}$ Further drug penetration is limited because the eye starts to heal and these barriers become more effective. Increasing the dose in this situation - in order to obtain sufficiently high therapeutic drug concentrations in the eye - could result in high concentrations in the blood, which could cause significant side effects. As can be seen from Table 1, the intake of a drug is primarily determined by its physicochemical properties. ${ }^{6}$ Table 1 gives an overview about the physicochemical properties of a drug
Table I Different drug absorption and elimination routes in the human eye

\begin{tabular}{ll}
\hline Absorption area & Drug \\
\hline $\begin{array}{l}\text { Cornea } \\
\text { Conjunctiva, sclera }\end{array}$ & $\begin{array}{l}\text { Lipophilic drugs } \\
\text { Lipophilic and } \\
\text { hydrophilic drugs } \\
\text { Lipophilic drugs }\end{array}$ \\
$\begin{array}{l}\text { From the blood via the blood-ocular barrier } \\
\text { From the blood via the blood-retinal barrier }\end{array}$ & $\begin{array}{l}\text { Lipophilic drugs } \\
\text { Hydrophilic and }\end{array}$ \\
$\begin{array}{l}\text { With lacrimal fluid via the trabecular meshwork } \\
\text { With lacrimal fluid via venous blood flow to the }\end{array}$ & $\begin{array}{l}\text { lipophilic drugs } \\
\text { Lipophilic drugs }\end{array}$ \\
$\begin{array}{l}\text { Out of the vitreous humor via the blood-retinal } \\
\text { barrier (back route) }\end{array}$ & Lipophilic drugs \\
$\begin{array}{l}\text { Out of the vitreous humor via the anterior } \\
\text { chamber of the eye (front route) }\end{array}$ & Hydrophilic and \\
\hline
\end{tabular}

and its absorption into (as well as corresponding elimination from) the eye. ${ }^{7,8}$

Diffusion of polar drugs across the lipid bilayer is limited and so transporters play an essential role in the absorption of molecules into the cells and the elimination of toxic compounds out of the cells such that cellular homeostasis is maintained. ${ }^{9}$

The multidrug resistance protein 1, also called P-glycoprotein, in the blood-retinal or blood-brain barrier protects the eyes and brain, respectively, from the toxic effects caused by the efflux of a variety of structurally diverse compounds. ${ }^{10,11}$ Additionally, influx transporters (eg, organic cation transporters, peptide transporters, or sodium-dependent multivitamin transporters) enable translocation of essential nutrients and drug molecules across cell membranes. ${ }^{12,13}$ In contrast, the systemic bioavailability of lipophilic drugs, such as betablockers, is high, and maximum plasma concentrations are reached rapidly. ${ }^{14}$ Their absorption here is mainly via the cornea, conjunctiva, and nasal mucosa. The lacrimal fluid is drained from the conjunctival sac through the nasolacrimal duct. The solution reaches the nasal cavity, where absorption can also occur through the nasal mucosa. Up to $80 \%$ of the applied drug(s) may diffuse into the systemic circulation by crossing the highly vascularized nasopharyngeal mucosa. An important property of absorption via this route is bypassing the liver. Due to this fact, first-pass metabolism is minimized compared to peroral administration. This depends, of course, on the drugs used but becomes especially relevant when using drugs with low absorption rates as it can then result in systemic adverse effects. ${ }^{15,16}$ In addition, the volume of commercial drop dispensers often exceeds the capacity of drug absorption of the conjunctival sac, so that some of the liquid can drain out of the eye and onto the eyelids and cheeks. ${ }^{17}$ However, because the transdermal transfer through 
the epidermis of most eye drugs is very low, this amount of resorption has only a negligible effect on systemic bioavailability. ${ }^{18}$ Currently, intravitreal injection is one of the most commonly performed medical procedures. ${ }^{19}$ After being injected, the drug is eliminated by two main routes: anterior and posterior. All compounds are able to use the anterior route. This means drug diffusion across the vitreous body to the posterior chamber and, thereafter, elimination via aqueous turnover and uveal blood flow. ${ }^{20}$ Posterior elimination takes place by permeation across the posterior blood-ocular barrier. This requires adequate passive permeability or active transporters across these barriers. For these reasons, higher molecular weights and good water solubility tend to increase the half-life in the vitreous body. ${ }^{1,20}$

\section{Pediatric considerations}

Infants are especially subject to much higher risks of systemic side effects. The eye of a newborn is approximately two-thirds of its adult size and does not reach adult size until around the age of 3 years or 4 years. ${ }^{21}$ The membranes in the eyes of newborns and infants are thin; so drug absorption and corneal permeation may be more rapid in these groups. The cornea of a newborn has $70 \%$ of the absorptive surface of the adult cornea, while the total intraocular volume is barely one-third of that of the adult eye. ${ }^{21}$ Basal tear volume increases with age. Typical volumes reported are $0.5 \mu \mathrm{L}$ for newborns, $2.5 \mu \mathrm{L}$ for older infants, and $6 \mu \mathrm{L}$ in adults. The age-related lower tear volume can lead to topically applied medications becoming concentrated in younger patients. It is estimated that a newborn requires only one-half of the adult dosage of eye drops to obtain an equivalent ocular concentration. Only two-thirds of the adult dosage is required at the age of 3 years, while it reaches $90 \%$ at the age of 6 years. ${ }^{22}$ Furthermore, ocular dosing is not weight adjusted and, therefore, pediatric patients are particularly vulnerable as drug metabolism is reduced in the young and/or an immature blood-brain barrier may be present. Contrary to the case of adults, pharmacokinetic-pharmacodynamic studies in pediatrics are extremely rare due to ethics and other aspects such as blood sampling. ${ }^{23}$ In particular, infants differ in their physiology, leading to altered pharmacokinetics and pharmacodynamics of a drug. Hence, there may be a necessity for customized pediatric delivery devices to provide smaller doses of topically applied ophthalmic preparations. ${ }^{24}$

\section{Data sources, searches, and extraction}

Four electronic databases (Medline, PubMed, PubMed Central, and Austria Data Source - Austria Codex) were searched for relevant articles published between October 1978 and January 2016 using combinations of key terms, which included "pharmacokinetics", "eye drops", "systemic side effects", "dosing", "pharmacodynamics", "CYP”, and "children". Reference lists of the included articles and key systemic reviews were also checked manually.

\section{Drug classes}

The following sheds some light on the possible adverse systemic side effects for some drug classes that are frequently prescribed.

\section{Antibiotics}

Bacterial inflammations of the eye are indeed much less common than other causes of inflammation but, when present, can often result in more serious diseases. Most ocular bacterial infections are treated with antibiotics, which may also cause systemic reactions. Some antibiotics have a wide therapeutic range; therefore, it is possible to administer these compounds systemically at high doses and thus they are used for treating the posterior regions of the eye which are normally difficult to access. Dermatological side effects, such as skin irritation, itching, or rashes, may be triggered by topical medications, eg, sulfonamide and sulfacetamide. ${ }^{17,25,26}$ It is also possible that fluoroquinolone can affect taste. ${ }^{27}$ Discontinuation of therapy is usually not necessary, but patients should be informed and warned about these probable side effects before starting or continuing treatment. The most popular aminoglycosides in use are tobramycin and gentamicin, which are often used in combination with a corticosteroid and have a wide spectrum of activity against bacteria, as well as neomycin, which is less frequently used. Local intolerances have been reported after the application of the aminoglycoside antibiotic neomycin such as the contact allergic reactions previously described. ${ }^{28}$

\section{Corticosteroids}

Ophthalmic steroids are therapeutically used for allergic or noninfectious conjunctivitis, to inhibit inflammation following cataract surgery, and in the treatment of acute anterior and chronic posterior uveitis. ${ }^{29}$ Moreover, they are also used in the fields of immunosuppression following transplantation and in the acute management of giant cell arteritis. ${ }^{29}$ Monotherapy administration of steroid drugs has a limited role in the therapy of bacterial ocular infections. Unfortunately, this group of drugs is often misused, leading to more severe infections and, possibly, permanent ocular damage. This group of drugs, especially when given over a prolonged time as a local or systemic therapy, can increase intraocular pressure. Therefore, the use of such drugs should be monitored 
closely to prevent the emergence of a so-called "cortisone glaucoma". Intraocular pressure should always be monitored in eyes receiving periocular corticosteroids. Furthermore complications of periocular corticosteroids include ocular hypertension, cataract, ptosis, inadvertent rupture of the globe, systemic toxicity, and uncontrolled hyperglycemia. ${ }^{30-33}$

Endothelial rejection remains a major cause of graft failure after penetrating keratoplasty. The use of topical corticosteroids is the gold standard for preventing rejection. ${ }^{34}$ In one study, the prolonged use of $0.1 \%$ fluorometholone was beneficial for the prevention of rejection after penetrating keratoplasty and no adverse systemic side effects were reported. ${ }^{34}$ Even endocrinological side effects from eye drops containing dexamethasone have also been described in clinical trials, albeit rarely and certainly are negligible..$^{35,36}$

Some products demand attention because of surprising properties. Loteprednol, for instance, belongs to a class of corticosteroids that have strong anti-inflammatory effects and were designed to achieve the expected effects directly at the area of application in order to reduce systemic adverse side effects. ${ }^{37}$ Its anti-inflammatory effect is comparable to that of effective steroids while having less effect on intraocular pressure. After ocular administration of loteprednol in healthy subjects, the results showed that both the unchanged drug and the metabolite were present systemically in low or even undetectable concentrations. ${ }^{37}$ The use of cyclodextrins (CDs) in addition to loteprednol eye drops delivers additional benefits. In general, CDs are known to improve the aqueous solubility of poorly soluble therapeutic preparations. Various studies have shown that using CDs in addition results in far greater drug concentrations being maintained in solution or by permeation through the cornea to achieve greater effect compared to the use of only the pure drug solution. ${ }^{38,39}$ In addition, an increased ocular bioavailability of loteprednol etabonate was detected ${ }^{38}$ However, CDs may also have negative effects on the eyes. ${ }^{40}$ For example, it cannot be completely ruled out that they could lodge themselves in the cornea or damage it by the dissolution of cholesterol and phospholipids. Moreover, liposomes are used as novel ophthalmic drug delivery carriers for treatment of ocular diseases. ${ }^{41}$ These techniques provide a convenient way of obtaining slow drug release and a reduction of possible systemic side effects.

\section{Sympathomimetics}

Vasoactive substances are commonly used to treat allergy symptoms or other types of noninfectious conjunctivitis. Phenylephrine, a selective $\alpha 1$-receptor and a weak base at physiological $\mathrm{pH}$, is also applied for dilating the pupils during ophthalmological examinations. ${ }^{42}$
Besides the possible dermatological side effects, such as contact dermatitis, adverse cardiovascular effects can become a serious complication. ${ }^{43}$ It is especially important to pay attention to these potential side effects when treating patients with existing hypertension conditions. ${ }^{44}$ Cases of massive increases in blood pressure, cardiac arrhythmias, and even myocardial infarction have been documented after the administration of phenylephrine eye drops. These reports describe incidents that mainly occurred after the administration of high-dose eye drops. ${ }^{45}$ Generally, a healthy cornea presents a physical barrier and the extent of drug penetration is determined by its condition. Where the corneal epithelium is damaged, the effect of the barrier and the extent of metabolism are reduced, leading to greater absorption. The risk of cardiovascular side effects, of course, decreases when medicinal products with a lower content of active substance are used. Nevertheless, an increased absorption even with these drugs could occur with a conjunctival hyperemia or epithelial damage to the cornea. Patients with hypertension, aneurysms, tachycardia, or cardiac disease must be treated with adequate caution. ${ }^{46}$ The use of phenylephrine $10 \%$ solution is not recommended (forbidden) for children and the elderly because of the increased risks of systemic toxicity. ${ }^{47,48}$

\section{Antisympathotonic agents}

The drug clonidine was originally developed as a decongestant drug. During clinical studies, it was found to be effective in reducing blood pressure. It was finally marketed for antihypertensive treatment by the drug maker with the name Catapressan ${ }^{\circledR} .49$ This drug was used in ophthalmology as it was proven to lower blood pressure after intravenous administration. The application of this drug may result in a pronounced reduction in blood pressure as a systemic side effect. ${ }^{50}$ Further clinical investigations led to the development of the $\alpha 2$ receptor agonist apraclonidine. This agent is recommended for short-term adjunctive therapy of chronic glaucoma in patients on maximally tolerated medical therapy who require additional intraocular pressure reduction to delay laser treatment or glaucoma surgery. ${ }^{51}$ Due to frequent local ocular intolerance, reactions such as hyperemia, pruritus, foreign body sensation, as well as eyelid and conjunctival edema may occur. Apraclonidine is of minor importance in long-term therapy and is now rarely used.

If apraclonidine is applied, possible systemic side effects such as dry mouth, dizziness, fatigue, and drowsiness can occur, especially in predisposed bradycardic patients. ${ }^{51}$ Even with the proprietary product Alphagan ${ }^{\circledR} 0.2 \%$ eye 
drops (active ingredient: brimonidine), there is information in the patient information leaflet that patients with cerebral or coronary conditions, Raynaud's phenomenon, orthostatic hypotension, or thromboangiitis should use this drug with caution. ${ }^{52-54}$

\section{Beta-receptor blockers}

Glaucoma is still nowadays unfortunately one of the main causes of blindness.

The medications most frequently used in the treatment of progressive damage to the optic nerve are beta-blockers. These ophthalmics reduce eye pressure by decreasing the production of intraocular fluid. There are both cardioselective and noncardioselective beta-blockers available on the market. Various dermatological side effects have been reported following topical application of this drug class. ${ }^{55-57}$ Individual patients have reported incidences of urticaria, alopecia, contact dermatitis, or psoriasiform rashes. ${ }^{58-60}$ In addition, various cardiovascular side effects such as bradycardia, arrhythmias, syncope, or hypotension have been observed after the administration of beta-blockers. ${ }^{61}$ Even cases of a transient ischemic attack and amaurosis fugax were described..$^{62}$ In predisposed patients such as asthmatics, beta-blockers can cause bronchoconstriction. ${ }^{63}$ For this reason, this drug group is not recommended for asthmatics. Particular caution is recommended when ophthalmic timolol is coadministered with paroxetine or other strong cytochrome P450 (CYP)-2D6 inhibitors. ${ }^{64}$ These comedications increase the plasma concentrations of timolol and thereby increase the risk of adverse cardiovascular effects.

\section{Parasympathomimetic agents}

This drug group was established more than 100 years ago for the treatment of glaucoma. Parasympathomimetics cause a contraction of the ciliary muscles to expand the trabecular meshwork in the anterior chamber angle.

Medicinal products derived from this group, such as pilocarpine eye drops, are very rarely prescribed these days. Systemic adverse effects were mainly reported following repeated use and included excessive sweating, bronchospasm, vomiting, diarrhea, bradycardia, and falls in blood pressure. ${ }^{65,66}$

In some cases, confusion and memory disorders were observed, as well as emotional lability, agitation, and concentration and behavioral disorders. ${ }^{67}$ Additionally, topically applied parasympathomimetic drugs may represent a potential cause of allergic contact dermatitis of the periorbital region. ${ }^{68,69}$

\section{Carbonic anhydrase inhibitors}

Inhibition of carbonic anhydrase in the ciliary body of the eye decreases aqueous humor production and thus reduces the intraocular pressure.

There are both oral and topically applied medicinal products available.

Orally applied acetazolamide has been an important glaucoma medication for a long time. However, it requires prolonged use and leads to frequent systemic side effects such as fatigue, loss of appetite, paresthesia, and depression. ${ }^{70}$ It can cause metabolic disorders such as hypokalemia, metabolic acidosis and, with prolonged use, even kidney stones. Because of the structural similarity, all carbonic anhydrase inhibitors should not be used in individuals who are allergic to sulfonamides. ${ }^{71-73}$ With the launch on to the market of topical carbonic anhydrase inhibitors, these orally applied drugs will only be used in the field of ophthalmology for a short time more. Dorzolamide and brinzolamide can be used topically in the treatment of ocular hypertension and primary open-angle glaucoma. These medicinal products produce less side effects compared to the first-generation drugs. ${ }^{74,75}$ Brinzolamide is reabsorbed from the blood to a small extent, which results in low systemic blood concentrations and only few side effects could be expected. ${ }^{72,75}$ Nevertheless, nausea and interference in taste may occur.

\section{Prostaglandins}

Latanoprost is a derivative of prostaglandin (PG)- $\mathrm{F}_{2 \alpha}$ and the first glaucoma medication from this group. As a prodrug, it is converted by corneal esterases into its active form during penetration into the eye. ${ }^{76}$ Latanoprost acid exerts its biologic activity at the PG-F ${ }_{2 \alpha}$ receptor. Systemic side effects are rare, but rashes, facial flushes, and increased perspiration all over the body have been reported in some individual cases. ${ }^{76-78}$

In very rare cases, the drug could also contribute to deterioration of symptoms in patients with asthma. Latanoprost may also sometimes cause minor local reactions, such as burning, stinging, itching, foreign body sensation, and increased lacrimation. The most striking observation is that latanoprost ophthalmic solutions cause changes to pigmented tissues. The most frequently reported changes have been increased pigmentation of the iris, periorbital tissue (eyelids), and eyelashes. ${ }^{79}$ Furthermore, it was also noted that it made the eyelashes darker, longer, and thicker. After discontinuation, pigmentation of the iris is likely to be permanent, while pigmentation of the periorbital tissue and eyelash changes have been reported to be reversible. ${ }^{79}$ Although these observations do not represent systemic side 
effects as such, they could be relevant in conversations with customers and are therefore included here for completeness. It should also be mentioned that many eye drops contain preservatives. Apart from some local irritation effects on the eye, long-term use of medicinal products with preservatives can cause physiological changes in the connective tissues. These changes could lead to "late" toxicities, for instance, in a subsequent glaucoma operation. The introduction of preservative-free antiglaucoma agents has become an important step toward improved glaucoma care by eliminating the negative effects of preservatives on the eye surface. In contrast to these findings, an actual publication reports that long-term topical application of preservativefree prostaglandin analogs evokes macrophage infiltration in the ocular adnexa. ${ }^{80}$

\section{Antihistamines and antiallergics}

$\mathrm{H}_{1}$-receptor blockers or mast cell-stabilizing agents such as sodium cromoglicate rarely result in systemic side effects after ocular administration. ${ }^{81,82}$ When they do, they usually manifest themselves as gastrointestinal symptoms by a dry mouth feeling or nausea, or through the central nervous system as a headache or drowsiness. ${ }^{83,84}$

\section{Nonsteroidal anti-inflammatory agents (NSAIDs)}

Topical NSAIDs are increasingly used in ophthalmic practice. Drugs of this class act as postoperative anti-inflammatory agents, in addition to possessing analgesic properties. ${ }^{85}$

In addition to rarely occurring gastrointestinal side effects, they can also cause unwanted respiratory events that represent a serious drug side-reaction. ${ }^{86-88}$

In several cases, patients reported the triggering of an acute asthma attack, possibly caused by an increased synthesis of bronchoconstrictor leukotrienes after the blocking of PG synthesis. ${ }^{89}$ Case reports on allergic contact dermatitis caused by diclofenac sodium eye drops exist but are extremely rare..$^{90,91}$

\section{Conclusion}

In ophthalmology, both local (eye drops, as well as subconjunctival and intravitreal applications) and systemic treatment approaches are used. Before the administration of eye drops, a complete medical checkup, including details of allergies and systemic diseases, should be carried out to detect probable risk factors (eg, bronchial asthma). Infants are especially vulnerable as a consequence of their inability to efficiently metabolize a drug (CYP deficits) and/or an immature blood-brain barrier (Table 2). Topical adrenoceptor blockers, topical and systemic carbonic anhydrase inhibitors, PG analogs, adrenoceptor agonists, parasympathomimetics, and combined preparations are available for use in children, but usually as an off-label indication. ${ }^{92}$ Therefore, it is important to recognize that serious side effects have been reported and measures to reduce systemic absorption should be taken. The systemic absorption of drugs from eye drops can be significantly reduced by following simple guidelines. ${ }^{93}$ No more than one drop should be applied into the eye. Further eye drops should be applied into the conjunctival sac. Digital nasolacrimal occlusion for 3 minutes or eyelid closure for 2 minutes immediately after application of the drops has been shown to reduce plasma concentrations significantly. ${ }^{94}$ Digital nasolacrimal occlusion involves applying gentle pressure over the tear duct with clean fingers. These methods will reduce dose-related adverse effects such as bradycardia with beta-blockers, but as they do not block systemic absorption completely, contraindications and precautions should still be observed. In addition, neither of these techniques eliminates the risk of non-dose-related effects such as hypersensitivity. The dangers regarding the application of eye drops demonstrate the need for careful patient information and education.

Table 2 Differences in activity of hepatic drug-metabolizing enzymes in infants and children

\begin{tabular}{|c|c|c|c|c|c|c|}
\hline $\begin{array}{l}\text { Development } \\
\text { PK Phase I } \\
\text { metabolism }\end{array}$ & $\begin{array}{l}\text { Premature } \\
\text { neonates }\end{array}$ & $\begin{array}{l}\text { Neonates } \\
\text { (<I mo) }\end{array}$ & $\begin{array}{l}\text { Early infant } \\
\text { (l-2 mo) }\end{array}$ & $\begin{array}{l}\text { Mid-infant } \\
\text { (3-5 mo) }\end{array}$ & $\begin{array}{l}\text { Late infant } \\
(6-18 \mathrm{mo})\end{array}$ & $\begin{array}{l}\text { Older child } \\
\text { and adults }\end{array}$ \\
\hline CYPIA2 & $\downarrow$ & $\downarrow$ & $\downarrow$ & $\downarrow$ & $\leftrightarrow$ & $\uparrow \uparrow$ \\
\hline CYP2C9 & $\downarrow$ & $\leftrightarrow$ & $\uparrow$ & $\leftrightarrow$ & $\uparrow$ & $\uparrow \uparrow$ \\
\hline CYP2D6 & $\downarrow$ & $\leftrightarrow$ & $\uparrow$ & $\uparrow$ & $\uparrow$ & $\uparrow \uparrow$ \\
\hline CYP2CI9 & $\downarrow$ & $\leftrightarrow$ & $\uparrow$ & $\uparrow$ & $\uparrow$ & $\uparrow \uparrow$ \\
\hline CYP2EI & $\downarrow$ & $\leftrightarrow$ & $\uparrow$ & $\uparrow$ & $\uparrow$ & $\uparrow \uparrow$ \\
\hline CYP3A4 & $\downarrow$ & $\leftrightarrow$ & $\uparrow$ & $\uparrow$ & $\uparrow$ & $\uparrow \uparrow$ \\
\hline CYP3A7 & $\leftrightarrow$ & $\uparrow$ & $\leftrightarrow$ & $\downarrow$ & $\downarrow$ & $\downarrow$ \\
\hline
\end{tabular}

Notes: Data from various studies. ${ }^{95-103}$ Copyright 2014. Adapted with permission from PPAG: the Pediatric Pharmacy Association. Lu H, Rosenbaum S. Developmental pharmacokinetics in pediatric populations. J Pediatr Pharmacol Ther. 20I4; I9(4):262-276. ${ }^{101}$

Abbreviations: $\downarrow$, low level; $\leftrightarrow$, intermediate level; $\uparrow$, higher level; $\uparrow \uparrow$, adult level; CYP, cytochromes P450; mo, months; PK, pharmacokinetics. 


\section{Disclosure}

The authors report no conflicts of interest in this work. The authors do not have any commercial or proprietary interest in the products discussed or their respective companies.

\section{References}

1. Worakul N, Robinson JR. Ocular pharmacokinetics/pharmacodynamics. Eur J Pharm Biopharm. 1997;44:71-83.

2. Peduzzi M, Debbia A, Monzani A. Ocular anatomy and physiology: its relevance to transcorneal drug absorption and to vehicle effects. In: Fidia Research Series. Liviana Press and Springer Verlag; 1987;11:1-6.

3. Järvinen K, Järvinen T, Urtti A. Ocular absorption following topical delivery. Adv Drug Deliv Rev. 1995;16(1):3-19.

4. Scruggs J, Wallace T, Hanna C. Route of absorption of drug and ointment after application to the eye. Ann Ophthalmol. 1978;10(3): 267-271.

5. Prausnitz MR, Noonan JS. Permeability of cornea, sclera and conjunctiva: a literature analysis for drug delivery to the eye. J Pharm Sci. 1998;87(12):1479-1488.

6. Hornof M, Toropainen E, Urtti A. Cell culture models of the ocular barriers. Eur J Pharm Biopharm. 2005;60(2):207-225.

7. Urtti A, Salminen L. Minimizing systemic absorption of topically administered ophthalmic drugs. Surv Ophtalmol. 1993;37(6):435-456.

8. Barar J, Aghanejad A, Fathi M, et al. Advanced drug delivery and targeting technologies for the ocular diseases. Bioimpacts. 2016;6(1): 49-67.

9. Pescina S, Govoni P, Antopolsky M, et al. Permeation of proteins, oligonucleotide and dextrans across ocular tissues: experimental studies and a literature update. J Pharm Sci. 2015;104(7):2190-2202.

10. Vadlapatla RK, Vadlapudi AD, Pal D, Mitra AK. Role of membrane transporters and metabolizing enzymes in ocular drug delivery. Curr Drug Metab. 2014;15(7):680-693.

11. Sethi S, Malik MA, Goswami S, et al. Expression of P-glycoprotein in human retinoblastoma and its clinical significance. Tumour Biol. 2014;35(12):11735-11740.

12. Hosoya K, Makihara A, Tsujikawa Y, et al. Roles of inner bloodretinal barrier organic anion transporter 3 in the vitreous/retinato-blood efflux transport of p-aminohippuric acid, benzylpenicillin, and 6-mercaptopurine. J Pharmacol Exp Ther. 2009;329(1):87-93.

13. Vadlapudi AD, Vadlapatla RK, Mitra AK. Sodium dependent multivitamin transporter (SMVT): a potential target for drug delivery. Curr Drug Targets. 2012;13(7):994-1003.

14. Munroe WP, Rindone JP, Kershner RM. Systemic side effects associated with the ophthalmic administration of timolol. Drugs Intell Clin Pharm. 1985;19(2):85-89.

15. Maurice DM, Mishima S. Ocular pharmacokinetics. In: Sears ML, editor. Handbook of Experimental Pharmacology. Berlin, Heidelberg: Springer Verlag; 1984:19-116.

16. Djebli N, Khier S, Griguer F, et al. Ocular drug distribution after topical administration: population pharmacokinetic model in rabbits. Eur $J$ Drug Metab Pharmacokinet. Epub 2016 Jan 28.

17. Diamond JP. Systemic adverse effects of topical ophthalmic agents: implications for older patients. Drugs Aging. 1997;11(5):352-360.

18. Xu X, Al-Ghabeish M, Rahman Z, et al. Formulation and process factors influencing product quality and in vitro performance of ophthalmic ointments. Int J Pharm. 2015;493(1-2):412-425.

19. Bashshur ZF, Bazarbachi A, Schakal A, et al. Intravitreal bevacizumab for the management of choroidal neovascularisation in age-related macular degeneration. Am J Ophthalmol. 2006;142(1):1-9.

20. Urtti A. Challenges and obstacles of ocular pharmacokinetics and drug delivery. Adv Drug Deliv Rev. 2006;58(11):1131-1135.

21. Batchelor HK, Marriott JF. Formulations for children: problems and solutions. Br J Clin Pharmacol. 2015;79(3):405-418.

22. Patton TF, Robinson JR. Pediatric dosing considerations in ophthalmology. J Pediatr Ophthalmol. 1976;13(3):171-178.
23. Ku LC, Smith PB. Dosing in neonates: special considerations in physiology and trial design. Pediatr Res. 2015;77(1):2-9.

24. Walsh J, Bickmann D, Breitkreutz J, Chariot-Goulet M; European Paediatric Formulation Initiative (EuPFI). Delivery devices for the administration of paediatric formulations: overview of current practice, challenges and recent developments. Int J Pharm. 2011;415(1-2):221-231.

25. Cetazin ${ }^{\circledR}, 10 \%$ Augentropfen (sulfacetamid). Austria Data Source-Austria Codex. Österr. Apothekerverlagsges.m.b.H. Vers.1.0 29/06 2016.

26. Kruyswijk MR, van Driel LM, Polak BC, Go-Sennema AA. Contact allergy following administration of eyedrops and eye ointments. Doc Ophthalmol. 1980;48(2):251-253.

27. Zoroxin ${ }^{\circledR}$, Augentropfen (norfloxacin). Austria Data Source - Austria Codex. Österr. Apothekerverlagsges.m.b.H. Vers.1.0 29/06 2016.

28. Betnesol $\mathrm{N}^{\circledR}$, Augen-, Ohren- und Nasentropfen (betamethason and neomycin). Austria Data Source - Austria Codex. Österr. Apothekerverlagsges.m.b.H. Vers.1.0 29/06 2016.

29. Krupin T, Mandell AI, Podos SM, Becker B. Topical corticosteroid therapy and pituitary-adrenal function. Arch Ophthalmol. 1976;94(6): 919-920.

30. Levin DS, Han DP, Dev S, et al. Subtenon's depot corticosteroid injections in patients with a history of corticosteroid-induced intraocular pressure elevation. Am J Ophthalmol. 2002;133(2):196-202.

31. Lafranco Dafflon M, Tran VT, Guex-Crosier Y, Herbort CP. Posterior sub-Tenon's steroid injections for the treatment of posterior ocular inflammation: indications, efficacy and side effects. Graefes Arch Clin Exp Ophthalmol. 1999;237(4):289-295.

32. Gopal L, Bhende M, Sharma T. Vitrectomy for accidental intraocular steroid injection. Retina. 1995;15(4):295-299.

33. Ozerdem U, Levi L, Cheng L, Song MK, Scher C, Freeman WR. Systemic toxicity of topical and periocular corticosteroid therapy in an 11-year-old male with posterior uveitis. Am J Ophthalmol. 2000; 130(2):240-241

34. Shimazaki J, Iseda A, Satake Y, Shimazaki-Den S. Efficacy and safety of long-term corticosteroid eye drops after penetrating keratoplasty: a prospective, randomized, clinical trial. Ophthalmology. 2012;119(4): 668-673.

35. Rotors S, Aspacher F, Distelhorst M. The influence of dexamethasone $0.1 \%$ eye drops on plasma cortisol and ACTH concentrations after cataract surgery. Ophthalmologica. 1996;210(4):211-214.

36. Scherrer KS, Weitz M, Eisenack J, Truffer B, Konrad D. Cushing syndrome after bilateral lensectomy. Eur J Pediatr. 2015;174(3): 399-401.

37. Lotemax, $0.5 \%$ Augentropfensuspension (loteprednol). Austria Data Source-Austria Codex. Österr. Apothekerverlagsges.m.b.H. Vers.1.0 29/06 2016

38. Soliman OA, Mohamed EA, El-Dahan MS, Khatera NA. Potential use of cyclodextrin complexes for enhanced stability, anti-inflammatory efficacy, and ocular bioavailability of loteprednol etabonate. AAPS PharmSciTech. Epub 2016 Jul 28.

39. Mester U, Lohmann C, Pleyer U, et al. A comparison of two different formulations of diclofenac sodium $0.1 \%$ in the treatment of inflammation following cataract-intraocular lens surgery. Drugs R D. 2002; 3(3):143-151.

40. Loftssona T, Jarvinen T. Cyclodextrins in ophthalmic drug delivery. Adv Drug Deliv Rev. 1999;36(1):59-79.

41. Short BG. Safety evaluation of ocular drug delivery formulations: techniques and practical considerations. Toxicol Pathol. 2008;36(1):49-62.

42. Jones J, Greenberg L, Groudine S, et al. Phenylephrine advisory panel report. Int J Pediatr Otorhinolaryngol. 1998;45(1):97-99.

43. Madsen JT, Andersen KE. Phenylephrine is a frequent cause of periorbital allergic contact dermatitis. Contact Dermatitis. 2015;73(1):64-65.

44. Lai YK. Adverse effect of intraoperative phenylephrine 10\%: case preport. Br J Ophthalmol. 1989;73(6):468-469.

45. Neffendorf JE, Mota PM, Xue K, Hildebrand GD. Efficacy and safety of phenylephrine $2.5 \%$ with cyclopentolate $0.5 \%$ for retinopathy of prematurity screening in 1246 eye examinations. Eur J Ophthalmol. 2015; 25(3):249-253. 
46. Stavert B, McGuinness MB, Harper CA, Guymer RH, Finger RP. Cardiovascular adverse effects of phenylephrine eyedrops: a systematic review and meta-analysis. JAMA Ophthalmol. 2015;133(6):647-652.

47. Venkatakrishnan J, Jagadeesh V, Kannan R. Pulmonary edema following instillation of topical phenylephrine eyedrops in a child under general anesthesia. Eur J Ophthalmol. 2011;21(1):115-117.

48. Calenda E, Richez F, Muraine M. Acute hypertension due to phenylephrine eyedrops in a newborn. Can J Ophthalmol. 2007;42(3):486.

49. Krieglstein GK, Langham ME, Leydhecker W. The peripheral and central neural actions of clonidine in normal and glaucomatous eyes. Invest Ophthalmol Vis Sci. 1978;17(2):149-158.

50. Isoglaucon ${ }^{\circledR}, 1 / 4 \%$ Augentropfen (clonidin). Austria Data Source Austria Codex. Österr. Apothekerverlagsges.m.b.H. Vers.1.0 29/06 2016.

51. Iopidine ${ }^{\circledR}, 0.5 \%$ Augentropfen (apraclonidin). Austria Data Source-Austria Codex. Österr. Apothekerverlagsges.m.b.H. Vers.1.0 29/06 2016.

52. Alphagan ${ }^{\circledR}, 0.2 \%$ Augentropfen (brimonidin). Austria Data Source Austria Codex. Österr. Apothekerverlagsges.m.b.H. CD-Rom. Vers.1.0 29/06 2016.

53. David R, Spaeth GL, Clevenger CE, et al. Brimonidine in the prevention of intraocular pressuare elevation following argon laser trabeculopasty. Arch Ophthalmol. 1993;111(10):1387-1390.

54. Levy Y, Zadok D. Systemic side effects of ophthalmic drops. Clin Pediatr (Phila). 2004;43(1):99-101

55. Betoptic ${ }^{\circledR}, \mathrm{S}-$ Augensuspension (betaxolol). Austria Data Source - Austria Codex. Österr. Apothekerverlagsges.m.b.H. Vers.1.0 29/06 2016.

56. Timoptic ${ }^{\circledR}, 0.25 \%$ Augentropfen (timolol). Austria Data Source-Austria Codex. Österr. Apothekerverlagsges.m.b.H. Vers.1.0 29/06 2016.

57. Shelley WB, Shelley ED. Chronic erythroderma induced by betablocker (timolol maleate) eyedrops. J Am Aced Dermatol. 1997; 37(5Pt1):799-800.

58. Quiralte J, Florido F, De San Pedro BS. Allergic contact dermatitis from carteolol and timolol in eyedrops. Contact Dermatitis. 2000;42(4):245.

59. Fraunfelder FT, Meyer SM, Menacker SJ. Alopecia possibly secondary to topical ophthalmic beta blockers. JAMA. 1990;263(11):1493-1494.

60. Gold MH, Holy AK, Roenigk HH. Beta-blocking drugs and psoriasis: a review of cutaneous side effects and retrospective analysis of their effects on psoriasis. J Am Acad Dermatol. 1988;19(5Pt1):837-841.

61. Leier CV, Baker ND, Weber PA. Cardiovascular effects of ophthalmic timolol. Ann Intern Med. 1986;104(2):197-198.

62. Coppeto JR. Transient ischemic attacks and amaurosis fugax from timolol. Ann Ophthalmol. 1985;17(1):64-65.

63. Nelson WL, Fraunfelder FT, Sills JM, et al. Adverse respiratory and cardiovascular events attributed to timolol ophthalmic solution 1978-1985. Am J Ophthalmol. 1986;102(5):606-611.

64. Mäenpää J, Volotinen-Maja M, Kautiainen H, et al. Paroxetine markedly increases plasma concentrations of ophthalmic timolol; CYP2D6 inhibitors may increase the risk of cardiovascular adverse effects of $0.5 \%$ timolol eye drops. Drug Metab Dispos. 2014;42(12):2068-2076.

65. Pilocarpin Puroptal ${ }^{\circledR}, 2 \%$ - Augentropfen (pilocarpin). Austria Data Source - Austria Codex. Österr. Apothekerverlagsges.m.b.H. Vers.1.0 29/06 2016.

66. Fraunfelder FT, Morgan R. The aggravation of dementia by pilocarpine. JAMA. 1994;271(22):1742-1743.

67. Reyes PF, Dwyer BA, Schwartzman RJ, et al. Mental status changes induced by eyedrops in dementia of a Alzheimer type. J Neurol Neurosurg Psychiatry. 1987;50(1):113-115.

68. Yasmeen JB, Sumaya Z, Iffat H. Allergic contact dermatitis to eye drops. Indian J Dermatol. 2015;60(6):637.

69. Holdiness MR. Contact dermatitis to topical drugs for glaucoma. Am J Contact Dermat. 2001;12(4):217-219.

70. Diamox ${ }^{\circledR}$, Tabletten $250 \mathrm{mg}$ (acetazolamide). Austria Data Source Austria Codex. Österr. Apothekerverlagsges.m.b.H. Vers.1.0 29/06 2016.

71. Azopt ${ }^{\circledR}, 10 \mathrm{mg} / \mathrm{ml}$ Augentropfensuspension (brinzolamide). Austria Data Source - Austria Codex. Österr. Apothekerverlagsges.m.b.H. Vers.1.0 29/06 2016.
72. Hertle RW, Yang D, Adkinson T, Reed M. Topical brinzolamide (Azopt) versus placebo in the treatment of infantile nystagmus syndrome (INS). Br J Ophthalmol. 2015;99(4):471-476.

73. Guedes GB, Karan A, Mayer HR, Shields MB. Evaluation of adverse events in self-reported sulfa-allergic patients using topical carbonic anhydrase inhibitors. J Ocul Pharmacol Ther. 2013;29(5):456-461.

74. Balfour JA, Wilde MI. Dorzolamide - a review of its pharmacology and therapeutic potential in the management of glaucoma and ocular hypertension. Drugs Aging. 1997;10(5):384-403.

75. Silver LH. The Brinzolamide Primary Therapy Study Group. Clinical efficacy and safety of brinzolamide (Azopt), a new topical carbonic anhydrase inhibitor for primary open-angle glaucoma and ocular hypertension. Am J Ophthalmol. 1998;126(3):400-408.

76. Alm A. Latanoprost in the treatment of glaucoma. Clin Ophthalmol. 2014;8:1967-1985.

77. Rowe JA, Hattenhauer MG, Herman DC. Adverse side effects associated with latanoprost. Am J Ophthalmol. 1997;124(5):683-685.

78. Schmidtborn F. Systemic side-effects of latanoprost in a child with aniridia and glaucoma. Ophthalmologe. 1998;95(9):633-634.

79. Xalatan ${ }^{\circledR}, 0.005 \%$-Augentropfen (latanoprost). Austria Data Source Austria Codex. Österr. Apothekerverlagsges.m.b.H. Vers.1.0 29/06 2016.

80. Trzeciecka A, Paterno JJ, Toropainen E, et al. Long-term topical application of preservative-free prostaglandin analogues evokes macrophage infiltration in the ocular adnexa. Eur J Pharmacol. 2016;788:12-20. Epub 2016 Jun 14.

81. Mösges R, Hassan HA, Wenzel MR. Optimal use of topical agents for allergic conjunctivitis. BioDrugs. 1997;8(4):250-264.

82. Castillo M, Scott NW, Mustafa MZ, Mustafa MS, Azuara-Blanco A. Topical antihistamines and mast cell stabilisers for treating seasonal and perennial allergic conjunctivitis. Cochrane Database Syst Rev. 2015;(6):CD009566.

83. Allergodil ${ }^{\circledR}$, Augentropfen (azelastin). Austria Data Source - Austria Codex. Österr. Apothekerverlagsges.m.b.H. Vers.1.0 29/06 2016.

84. Vividrin ${ }^{\circledR}$, Augentropfen (cromoglicic acid disodium). Austria Data Source - Austria Codex. Österr. Apothekerverlagsges.m.b.H. Vers.1.0 29/06 2016

85. Voltaren ${ }^{\circledR}$, Ophtha Augentropfen (diclofenac). Austria Data Source Austria Codex. Österr. Apothekerverlagsges.m.b.H. Vers.1.0 29/06 2016.

86. Polachek A, Shvartzman P. Acute bronchial asthma associated with the administration of ophthalmic indomethacin. Isr J Med Sci. 1996; 32(11):1107-1109.

87. Sharir M. Exacerbation of asthma by topical diclofenac. Arch Ophthalmol. 1997;115(2):294-295.

88. Sheehan GJ, Krutzner MR, Chin WD. Acute asthma attack due to ophthalmic indomethacin. Ann Intern Med. 1989;111(4):337-338.

89. Sitenga GL, Ing EB, Van Dellen RG, Younge BR, Leavitt JA. Asthma caused by topical application of ketorolac. Ophthalmology. 1996;103(6): 890-892.

90. Miyazato H, Yamaguchi S, Taira K, et al. Allergic contact dermatitis due to diclofenac sodium in eye drops. J Dermatol. 2011;38(3): 276-279.

91. Gaynes BI, Fiscella R. Topical nonsteroidal anti-inflammatory drugs for ophthalmic use: a safety review. Drug Saf. 2002;25(4):233-250.

92. Samant M, Medsinge A, Nischal KK. Pediatric glaucoma: pharmacotherapeutic options. Paediatr Drugs. 2016;18(3):209-219.

93. Shaw M. How to administer eye drops and eye ointment. Nurs Stand. 2016;30(39):34-36.

94. Flach AJ. The importance of eyelid closure and nasolacrimal occlusion following the ocular instillation of topical glaucoma medications, and the need for the universal inclusion of one of these techniques in all patient treatments and clinical studies. Trans Am Ophthalmol Soc. 2008;106:138-145.

95. Treluyer JM, Jacqz-Aigrain E, Alvarez F, Cresteil T. Expression of CYP2D6 in developing human liver. Eur J Biochem. 1991;202(2): $583-588$. 
96. Koukouritaki SB, Manro JR, Marsh SA. et al. Developmental expression of human hepatic CYP2C9 and CYP2C19. JPharmacol Exp Ther. 2004; 308(3):965-974.

97. Lacroix D, Sonnier M, Moncion A. et al. Expression of CYP3A in the human liver-evidence that the shift between CYP3A7 and CYP3A4 occurs immediately after birth. Eur J Biochem. 1997;247(2):625-634.

98. Sonnier M, Cresteil T. Delayed ontogenesis of CYP1A2 in the human liver. Eur J Biochem. 1998;251(3):893-898.

99. Stevens JC, Marsh SA, Zaya MJ. et al. Developmental changes in human liver CYP2D6 expression. Drug Metab Dispos. 2008;36(8): $1587-1593$.

100. Hines RN. Ontogeny of human hepatic cytochromes P450. J Biochem Mol Toxicol. 2007;21(4):169-175.
101. Lu H, Rosenbaum S. Developmental pharmacokinetics in pediatric populations. J Pediatr Pharmacol Ther. 2014;19(4):262-276.

102. Treluyer JM, Gueret G, Cheron G. et al. Developmental expression of CYP2C and CYP2C-dependent activities in the human liver: in-vivo/in-vitro correlation and inducibility. Pharmacogenetics. 1997; 7(6):441-452.

103. Vieira I, Sonnier M, Cresteil T. Developmental expression of CYP2E1 in the human liver. Hypermethylation control of gene expression during the neonatal period. Eur J Biochem. 1996;238(2):476-483.
Clinical Ophthalmology

\section{Publish your work in this journal}

Clinical Ophthalmology is an international, peer-reviewed journal covering all subspecialties within ophthalmology. Key topics include: Optometry; Visual science; Pharmacology and drug therapy in eye diseases; Basic Sciences; Primary and Secondary eye care; Patien Safety and Quality of Care Improvements. This journal is indexed on

Submit your manuscript here: http://www.dovepress.com/clinical-ophthalmology-journal

\section{Dovepress}

PubMed Central and CAS, and is the official journal of The Society of Clinical Ophthalmology (SCO). The manuscript management system is completely online and includes a very quick and fair peer-review system, which is all easy to use. Visit http://www.dovepress.com/ testimonials.php to read real quotes from published authors. 